\title{
A UNIQUE SPATIAL PRACTICE FOR TRANSFORMING THE SOCIAL AND CULTURAL PATTERNS: ATATÜRK FOREST FARM IN ANKARA (1) Duygu KAÇAR
}

Received: 28.12.2010, Final Text: 10.05.2011

Keywords: culture; agri-culture; production; education, development, civilization, meaning; representation; spatial practice; Atatürk Forest Farm.

1. This paper provides a summary of a dissertation recently completed by the author (Kaçar, 2010) in the Program of Architecture, at the Department of Architecture, Faculty of Architecture, METU. The primary sources were gathered from the institutions of Atatürk Archive of Presidency of the Republic of Turkey, Ankara; Republic Archive of Prime Ministry of Turkey, Ankara; Library of Congress, Washington, DC; The U.S. National Archives and Records Administration, Washington, DC; U.S. Department of Agriculture, Washington, DC; ETH Bibliothek, Zurich; Vehbi Koc and Ankara Research Center (VEKAM), Ankara and from the METU Department of City and Regional Planning Maps and Plans Documentation Unit, Ankara as well. The author also would like to express her gratitude to her advisor Prof. Dr. Baykan Günay and the jury members Prof. Dr. Ali Cengizkan, Prof. Dr. Alan Lessoff, Assoc. Prof. Dr. Guven Arif Sargin and Assoc. Prof. Dr. Adnan Barlas for their valuable contributions and suggestions.
Atatürk Forest Farm is a unique spatial practice representing the main philosophy of the Turkish Republic. This private farm of Mustafa Kemal was established in 1925, with the goals of creating a new society by bringing together modern agricultural and industrial production techniques, combining them with leisure activities and developing an urban farm. Consequently, Forest Farm is discussed neither as a land problem nor as a heritage issue in the present paper. Its being is evaluated as a conscious contribution for the cultural transformation of the Turkish nation. Therefore, its genesis is elaborated in relation to the main definitions of culture in history: 1 . 'cultivating nature' with the idea of increasing the efficiency in products and lands. 2. 'cultivation of minds' in relation to the education of human beings'. 3. the 'process of social development'. 4. 'meanings, values, ways of life'. 5. 'practices which produce meanings' (Bocock, 1992, 234) and finally 6. the meshing of anthropological views linking the two definitions of 'a way of life' and 'the production of meaning' as 'a network of representations' (Frow and Morris, 1993, viii). All the ideologies and scientific knowledge are mentioned in addition to clarify this main argument. Thus, ideology, space and production are the complementary discussions to the main argument, culture. As an overall structure, the findings and conclusions will be given sequentially under the definitions of culture.

\section{CULTIVATING LAND, CROPS, ANIMALS}

Cultivating nature, the earliest definition of culture, emerged with the idea of efficiency in production and improvement of lands. In fact, cultivating the lands and production were the main themes for a better living after the Great War, too. While the world was witnessing new revolutionary regimes, most of the nations were facing food shortages, and selfsufficiency became the keyword in many countries. Accordingly, with the aim of releasing Italy from its dependence on food imports, Mussolini 
declared extensive land reclamation in 1920s and 1930s. In 1923 and 1924, he passed laws for agriculture and for socio-economic development. In parallel with the Fascist conception of progress, The Battle for Grain (La Battaglia del Grano) started in Italy in 1925. Therefore, cultivating nature was a major priority for Mussolini, in line with the Fascist ideology of triumph over nature. Consequently, he founded more than seventy towns and rural settlements between 1926 and 1940. The most well known project of the Italian leader was Pontine Marshes (Agro Pontino in Italian). The Italian state drained approximately $800 \mathrm{~km}^{2}$ land at southeast of Rome starting form 1926 (Wikipedia.org, 2010). With this project, former swamp and infertile lands of Pontine region were turned into farm units to promote agriculture. The cultivated lands were distributed to inhabitants according to the size of the family.

Subsistence was a critical issue in the New Deal America, too. Franklin Delano Roosevelt mentioned in the campaign of 1928 that the progressive decline in agriculture was a thing of danger. The United States, which was already an industrialized country, entered the worst depression in its history in 1929. Between 1930 and 1933, decreasing farm incomes, surpluses and lack of demand forced many farmers off the land. When FDR took office in 1933, one quarter of the population was unemployed. With his New Deal, Roosevelt encouraged the people of America to overcome the economic depression, in part with scientific land management, efficient farm production, and the restoration of community life (Seligman and Cornwell, 1965, xiii). Also as a precautionary measure for the population flow from rural toward cities; Roosevelt submitted self-supporting welfare projects beginning from 1933. Tennessee Valley Authority (TVA), an enormous cooperative power and land reclamation project, and Experimental Subsistence Homesteads, a self-supporting welfare project, were pioneer examples of the rural development features of the New Deal. Moreover, the Roosevelt administration pursued maximum employment all over the United States with Work Progress Administration (WPA) starting 1935. These projects of the New Deal were essential for Americans to survive in Great Depression years and for Roosevelt to be elected in the following three elections.

These two cases of Italy and the United States developed at the same period can be compared to the rural enterprises undertaken in Turkey. Beginning in 1925, approximately $150 \mathrm{~km} 2$ barren and swamplands close to the new capital of the Turkish Republic was cultivated with scientific knowledge in Forest Farm. For Mustafa Kemal, it was important to prove that human determination, know-how, and hard work would turn the most infertile soil into very productive land. Consequently, these were the first afforested lands of the new capital city. This forest in the barren lands of Anatolia became the symbol of the battle against nature. By cultivating the swamp and barren lands along the railway, Mustafa Kemal overcame the prejudices against the formerly isolated town of Ankara. In this way, he also proved to the opponents of the Republic that fertility is only possible by being open-minded, and progress begins with the will of the individual. Consequently, Ankara gained political, economic and social character as well as improving its status against İstanbul, the former capital of Ottoman Turkey.

Not only the cultivation of lands, but also the education of people, the progress of the society and social development were the common objectives of Turkish, Italian and American cases. Therefore, culture can 
be considered as a design for living for all of the three cases. However, the cases in Italy and in the United States are also evaluated as attempts to prevent migration from rural areas towards cities. For some scholars, by keeping the inhabitants away from the growing cities, the projects of relief and land distribution in 1930s helped to preserve capitalism both in Italy and in the United States (Ghirardo, 1989). Moreover, the fact of moving the families to cultivate the land from the other parts of Italy is considered an internal colonialism (Caprotti, 2007, 651-79). In the light of these discussions, our case differs from its contemporaries in Italy or in the United States. Forest Farm is neither a precaution against population flow nor an artificial environment for colonialism. It is a model production space for the young Turkish Republic, which was not industrialized in that period yet. The naïve intentions of civilization and industrialization with only the national resources through the notion of culture make Forest Farm a unique case in comparison to the other examples.

\section{CULTIVATION OF MIND}

The broadening definition of culture in the seventeenth and eighteenth centuries was the 'education of human beings'. Mustafa Kemal, too, sometimes used the word 'culture' instead of the word 'education' in his speeches. In his own words, "When talking about an education program, I am implying a culture in relation to the characteristics of our nation and history, but not the effects of superstitions of old times and foreign ideas that do not suit our creation." (Atatürk, in Duru, 1947, 12). To him, for a complete development of our nation, the suitable culture was in the character of our nation.

For an independent economic and industrial life in Turkey, education was singled out for reform. For a national development, the education had to include practical knowledge but also social values. From the 1890s on, progressive educators in the United States were introducing nature study into the curriculum of their schools. They also concerned themselves with issues of scientific production and efficiency, as well as the restoration of community life. Namely in the 4-H Clubs, young girls and boys were educated to be self-reliant and useful citizens for their country. While learning by doing, they were becoming participating, creative and self-sufficient members of society. Specifically, they were the ones to experiment new agriculture methods and then share their experiences with adults.

2. From 1919 to 1921, Dewey traveled extensively in China and lectured at national universities at Peking and Nanking. As Miss Jane Dewey mentions, “His visits to Turkey in 1924 and to Mexico in 1926 confirmed his belief in the power and necessity of education to secure revolutionary changes to the benefit of the individual, so that they cannot become mere alterations in the external form of a nation's culture." (Dewey, 1939, 39). His visit to Russia in 1928 impressed him as well, but later events in Russia made him criticize Soviet totalitarianism. The Turkish process of building the Republic and cultivating nation affected his intellectual world as well.

3. John Dewey's preliminary report, Source: The U.S. National Archives and Records Administration, Washington. DC.

4. Dewey prepared his comprehensive report on Turkish education system after he returned to America.
The most famous progressive educator, Professor John Dewey (2) of Columbia University, was invited to Turkey in 1923 (Figure 1) and was defined as 'the first foreign advisor on culture' in archive records. In contrast to teaching theoretical knowledge, Dewey considered education as integrating students into real life as human beings, individuals and citizens. In his view of 'learning by doing', the students would improve their capacities in experiential environments, namely in 'open air' and 'semi-open air' schools, for a successful life (Figure 2) (3). The subjective experience of individuals was important to the American philosopher Dewey. In his report on education in Turkey, he suggested experiential works for female students with males (Figure 3)(4). Accordingly, Mustafa Kemal discussed on progressive education with Professor Dewey during the Congress of Turkish Teachers' Association held in Ankara, on August 22, 1924. Soon after, in his speech on August 28, 1924, the president of Turkey underlined that the practice of education (talim ve terbiye) of our 

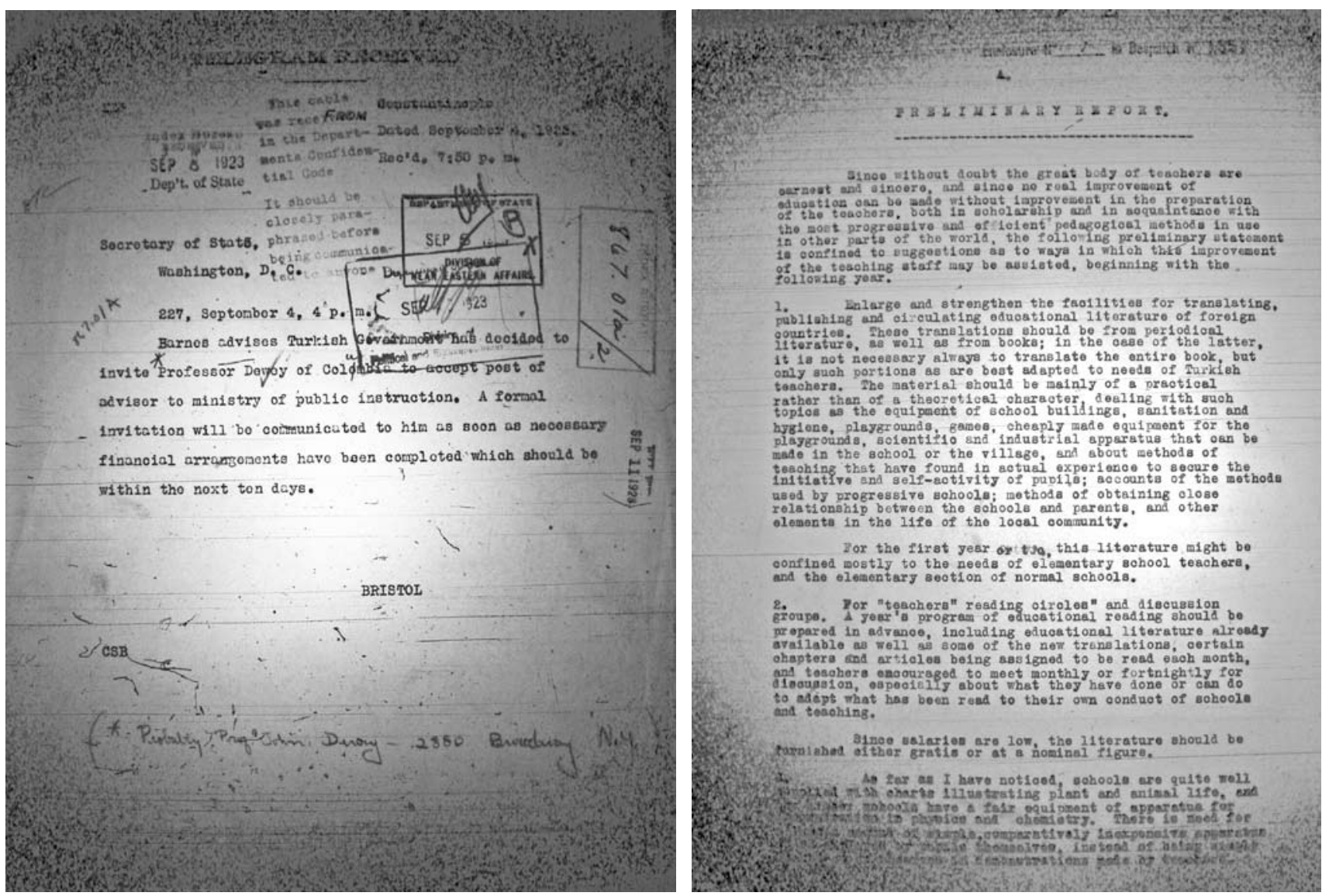

Figure 1. The telegram dated September 4, 1923 was asking John Dewey to accept the post of advisor to Ministry of Public Instruction. Source: The US National Archives and Records Administration, Microcopy No. 353, Records of the Department of State Relating to Internal Affairs of Turkey, 1910-29, Roll 22, 867.01a/2, Telegram Dated September 4, 1923.

Figure 2. The cover page of John Dewey's Preliminary Report for Turkish Education System. Source: The U.S. National Archives and Records Administration.
5. “Erkek ve kız çocuklarımızın, aynı sûretle, bütün tahsil derecelerindeki talim ve terbiyesinin amelî olması mühimdir. Memleket evlâdı her tahsil derecesinde iktisadî hayatta âmil, müessir ve muvaffak olacak sûrette techiz olunmalıdır" (Ata). boys and girls should be based on 'practice' in all levels (5). Moreover, he also declared that the youth of our nation should be provided with knowledge for their success and efficiency in industrial life.

It is not clear whether the view of Mustafa Kemal on the education of young generation with practical knowledge has emerged from the ideas of Dewey on learning by doing. However, it is obvious that, Mustafa Kemal employed young generations in Forest Farm to educate them on their own ground with their own experiences. Both the children of peasants and the students of the Higher Agricultural Institute had on-site education at the Farm. Specifically, graduates of high schools had to have ten-month practice in Forest Farm in order to attend the Higher Agricultural Institute (Figure 4). Therefore, between 1930 and 1938, 323 students (30 girls and 293 boys) experienced all positions in the Forest Farm including farm management. These young citizens between 14 and 17 were also learning how to use and repair farm machines while working in the factories of the farm. After getting their certificates, these young people were eligible for employment in the management of Forest Farm or in any other State Agricultural works.

This experience in Forest Farm would make the young generations aware of the needs of the nation, and they would become the ones to educate others (i.e. peasants). They were the ones who believed in science, knowledge and the well-being of Turkey.

Consequently, apart from the traditions, these young generations had a mission of cultivating all of Anatolia with scientific knowledge and 


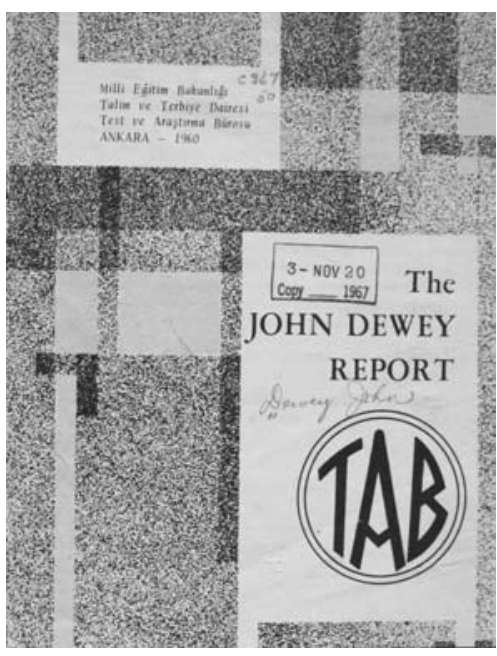

Figure 3. The cover page of The John Dewey Report. Source: Library of Congress, USA.
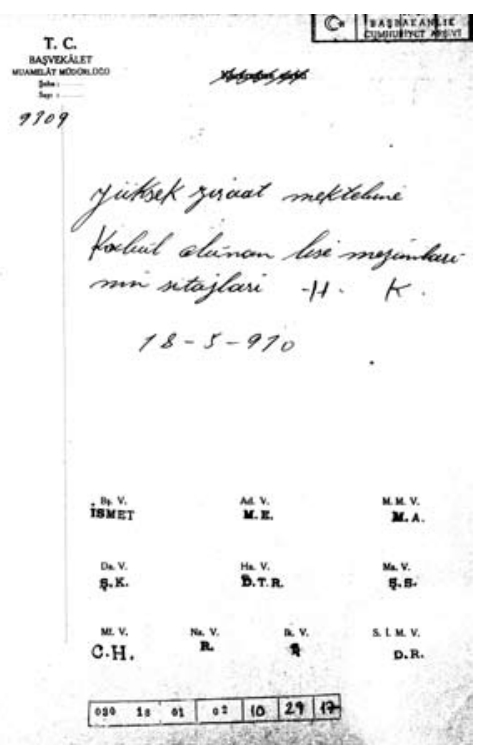

Figure 4. Ten months practice in Forest Farm was a prerequisite for Higher Agricultural Institute. The cover of the law for ten months practice in Forest Farm. Graduate students of high schools were educated in Forest Farm in order to attend Higher Agricultural Institute. Source: Republican Archive, Decisions of Cabinet, Date 18.05.1930, Code 030.18.1.2, Place No 10.29.17, Folder No 9309, Decision No K1695. technology. More than producing science, Forest Farm had a mission of spreading modern production techniques by educating youth. In this sense, Forest Farm was also an open-air school, in which boys and girls were educated together in practical knowledge, in the real conditions of real life, in science and technology.

\section{PROCESS OF SOCIAL DEVELOPMENT}

The term culture was used for 'the progress of society' by the late eighteenth century. All individuals dealing with land, agriculture and production were the subjects of cultivation. Beginning from 1870s, the education of peasants was agreed to be an approach for economic development first in Russia, then in Bulgaria and in Eastern Europe. According to this view, the peasant was the backbone of the nation. After the WWI, the peasant was idealized as the base of the nation in German, Russian and English literature (Karaömerlioğlu, 2006, 54). There was an aim of creating a society of well-educated and productive peasants, who were the good citizens. However, these 'back to the soil' experiments in modern and industrialized countries are also evaluated as a kind of precautionary measure against population flow from rural areas towards cities (Kirk, ed., 2005, 67; De Grand, 1995, 48). Legal obstacles to urban migration in Nazi Germany and Fascist Italy can be a concrete proof of this assertion.

On the contrary, the Ottoman Empire was not an industrialized country before WWI. Neither the idea of creating model villages in 1918 by Reşit Galip, nor the founding of the Peasants Society in 1919 by Halide Edib was related to the preservation of capitalism. European investors or ethnic minorities controlled the limited industry in Turkish lands and determined both the quality and the quantity of production. European trade, on which Turkish economy was extremely dependent, was also supported by international laws that made it privileged. Therefore, after the Great War, economic self-sufficiency was a necessity for the young republic's survival and independence.

The new regime aimed at economic development for a self-governing nation against the imperialist attempts of West. However, the people were poor and tired after the long and grueling wars. Peasants were also disadvantaged in trade because limited products, in turn subject to heavy taxation. Still, the largest portion of the population earned their living from agriculture. For that reason, the peasant was the main producer, and agriculture was the base of the national economy. Accordingly, in his opening speech of the first term of the third year of the nationalist parliament, on March 1, 1922 Mustafa Kemal declared the peasant as the real possessor and the master of Turkey. In order to provide rural rights and benefits, the Turkish government outlined new policies in the first Turkish Economy Congress between February 17 and March 4, 1923. Here, the president of Turkey declared that, these lands of hardworking people should be cultivated with technical tools and be connected to each other by railways and highways for commerce. Because of the competitive environment, the young generation should be educated in schools to be successful, effective and creative in the fields of agriculture, commerce and arts.

In the light of the decisions made by this congress, the agriculture sector was encouraged with laws, land reforms, an Agriculture Bank, agriculture 
Figure 5. The model farmer Mustafa Kemal. Source: METU Department of CRP Maps and Plans Documentation Unit.

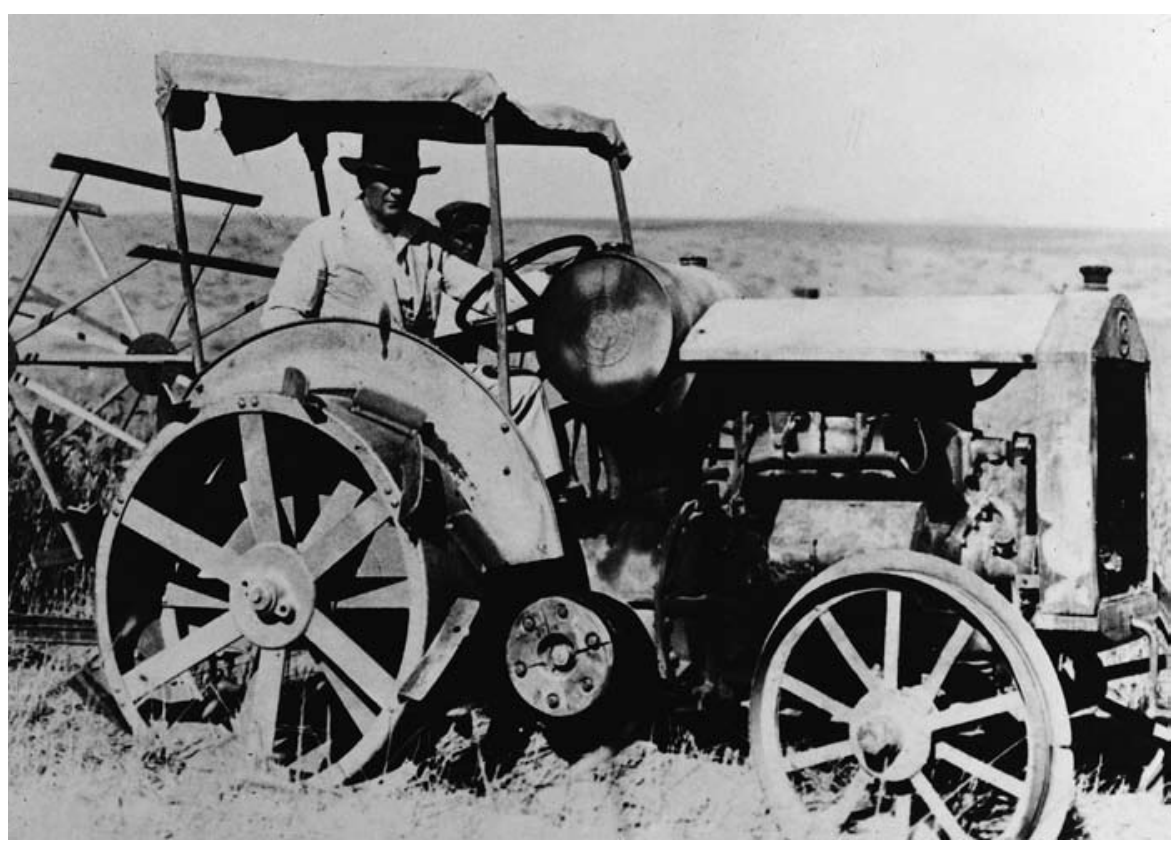

credit cooperatives, Dry Farming Stations, and agriculture schools and institutes in the following years. Forest Farm was established in such a period along with the Crop Cultivation and Production Institutes.

Forest Farm was among the new foundations for the economic development of the country. Since Mustafa Kemal was a real supporter of science, he created his experimental farm to make it a model for the entire population in this development process. Moreover, he personally demonstrated new tools, vehicles and scientific methods in this modern environment for a widespread use (Figure 5). Modern tools and methods offered the only way to increase production with less effort after the WWI. Efficiency in agriculture was also the only way of freeing more people to work in other areas like science, industry and arts. Through the education of the young generations at the farm, the peasants would also be educated and be given all kinds of samples not only for agricultural but also for technical stock raising and for breeding. This would help them to improve their products and sell them effectively both in national and international markets. Moreover, the ways of preserving the products, instructions on health of both crops and animals, technical support for farm machines were all demonstrated at Forest Farm for the information of the nation. This experimental environment was the 'laboratory' for the scientifically produced farm resources. Therefore, Forest Farm is directly a part of the development model of the young Turkish Republic and its anti-imperialist war of existence.

\section{MEANINGS, VALUES, WAYS OF LIFE}

In the late nineteenth and early twentieth centuries, the new discipline of anthropology defined culture as 'the sum of meanings, values and ways of life of a particular group'. Concentrating on 'what culture is', this definition took account of everything from technology to religion, as well as the interactions between the individuals and society. Culture was 'a design for living' for this view. Accordingly, Turkish intellectuals started to question the relations between individuals and society with the influence 
of the Narrodnichevstvo movement, which began in 1870s in Russia (Berkes, 2002,81 ). These intellectuals could see that a new social order was required for the enlightenment of the society. However, no complete revolution occurred until the expulsion of the Ottoman dynasty.

The societal reforms and revolutions of the new Republic sought popular enlightenment and the creation of a new Turkish citizen. For Mustafa Kemal, civilization was nothing other than culture. Consequently, he identified culture as the basis of the Turkish Republic and redefined Turkish culture, which would produce this new citizen. According to him, culture was "a life style based on science and knowledge, a route to open out to the contemporary world and join it as a whole, a belief of success to bring welfare, peace and happiness to Turkish society" (Güvenç, 2003, 35). However, the main historical and cultural characteristics of Turkish nation, such as an independent spirit, would never be lost. For preserving our independence, science and technology were prerequisites. To Mustafa Kemal, we would take science and technology wherever they were, and place them in minds of all individuals (Duru, 1947, 17). Superficial differences with western countries, such as the weekend holiday, calendar, measurement units and so on would be removed, leaving behind the influences of Arabic or Persian culture. This was a way of living on the civilization level as an advanced and developed nation.

The nationalist reforms transformed everyday life throughout the country, but above all in the new capital. However, only a limited group of intellectuals and bureaucrats were familiar with these new patterns of life. In Ankara, this political class adopted the modern way of life favored by the republic. Nevertheless, new institutions and notions were required for creating a completely different structure of society and state. Gazi Forest Farm, established early in the Republic, became one of those institutions that demonstrated the new culture in Ankara. The inhabitants of the capital could benefit from visual contact with the country's founders and practice the new style of living in the newly established settings of the Farm. In particular, even the construction of pools at Forest Farm was a matter of pride, since the lack of a sea made Ankara seem deficient by comparison to İstanbul. Swimming or sailing in Marmara and Akdeniz pools, watching the swimming races or having a swimming course in Karadeniz pool, eating in the Farm Restaurant, drinking in the Beer Park, exploring the zoo, walking around parks of Çiftlik Köşk, listening to the concert of the presidential orchestra around Marmara Köşk or hiking in the forest helped to associate the inhabitants with the new culture. Contrary to the ones in Mamak, Kayaş or Hatipçayı (Hatip stream), the inhabitants of Farm Park, Marmara and Karadeniz had an advanced view, according to the articles in the newspapers of the period (Figure 6). According to these articles, the environments associated with traditional culture should also be transformed for the sake of national unity. Forest Farm was the setting of the new regime, and it was a reflection of Ankara's civilized life.

On the other hand, the Farm also saw an attempt to search for 'what and how does Mustafa Kemal, with or without whom'. On the other hand, the Farm was a place in which the inhabitants were observing the attitudes and the personal life of Mustafa Kemal. By being there, the citizens had a chance of observing their leader in his Farm and feeling his existence in their everyday life. Moreover, those who felt themselves as a part of the new regime needed to be seen there. Consequently, not only for the students of the Agriculture Institute of Ankara or the peasants, but for the 
Figure 6. “Ankaralının Mamak, Kayaş, Hatipçayındaki görünüşü geri, Çiftlik Parkı, Marmara, Karadenizdeki görünüșü ileridir... Çiftlik Ankaranındır. Ve Kayaş, Mamak? Nerenindir biliyor musunuz? Eyüp'ün, Edirnekapı'nın, Tanzimat'ın..." The view of inhabitants around Mamak, Kayaş, Hatipçayı seemed backward; but in the Farm Park, around the Marmara and Karadeniz pools), they seemed advanced. The Farm belonged to Ankara, however Kayas and Mamak belonged to Eyüp, Edirnekapı that equals to Ottoman Empire. Source: Hakimiyet-i Milliye, 19.08.1933.

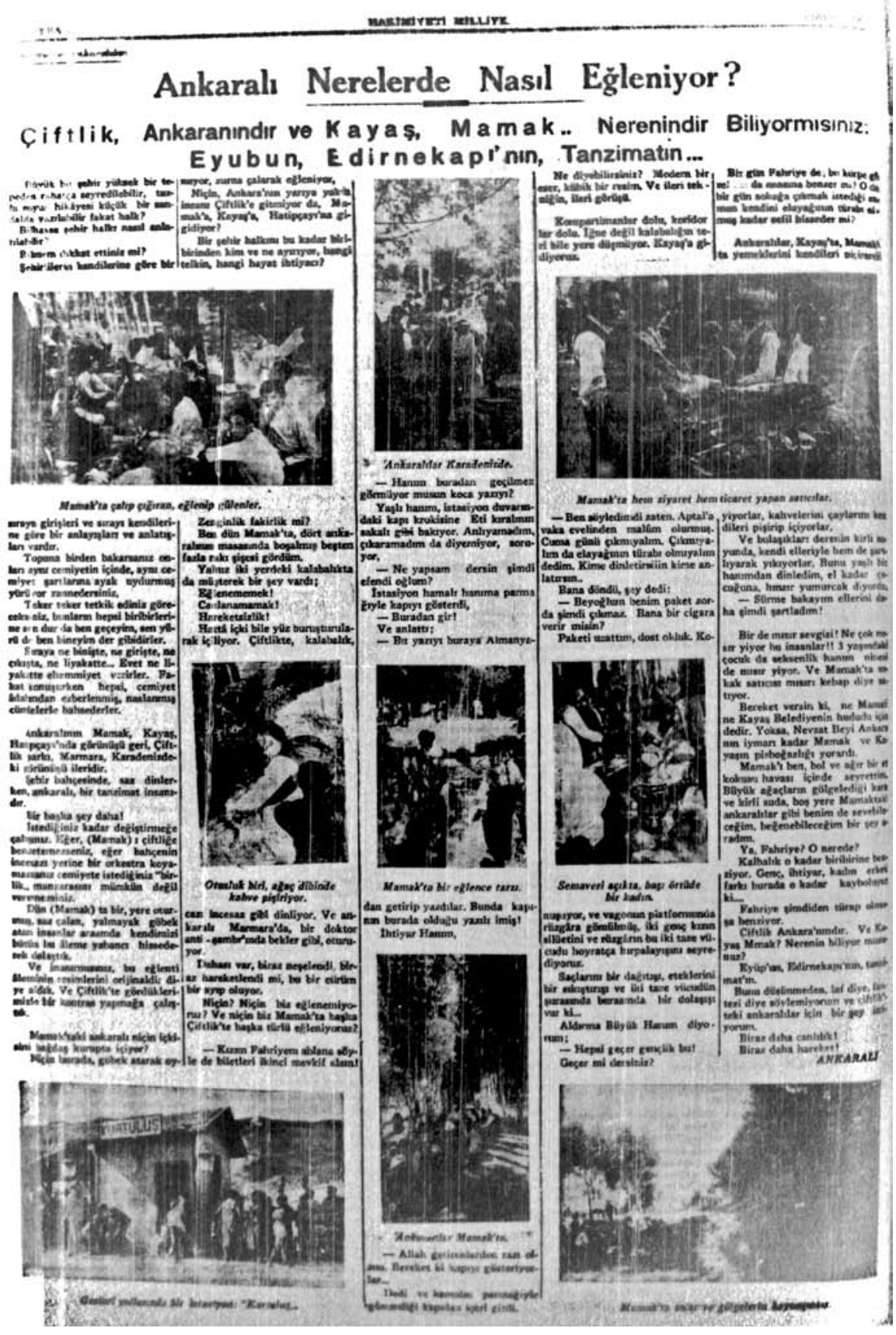

inhabitants of Ankara generally, Forest Farm had a transformative effect. Therefore, it can be defined as an open-air school again, but for inhabitants this time. For shaping the interactions between the individuals and society as well as forming the environment for new gender relations, Forest Farm meant civilization to the inhabitants in the nucleus of the new nation-state.

\section{PRACTICES WHICH PRODUCE MEANINGS}

Another definition derived from anthropology concentrates on culture as 'the social practices that produce meanings'. This approach focuses on symbolic values, rituals and activities produced in social reality and everyday life. In the early republican period, modern urban planning 
and architecture were among the common set of meanings that were constructed by the new political power and its philosophy.

While establishing the nation-state, the Turkish Republic deliberately transferred the previous capital city function of the Ottoman Empire from İstanbul to the formerly rural town of Ankara. Along with other geographic advantages, such as being the geometric centre, close to Anatolian provinces and far from threats that the İstanbul on the Bosphorous was open to, the construction of the new capital aimed at the display of the political power of the new regime and its search for legitimacy. The founders of the nation focused on creating a feeling of national identity with the help of manipulative power of the built environment. The physical appearance of modern nation-state was based on the principles of modern urban planning and architecture. This would help to leave any sign and symbol of the past behind. Therefore, Ankara as the first designed city in Turkey was the symbol of the newly emerging nation state.

Transforming social and cultural values, for modern 'citizens' of the society, was an important stage in the construction of the nation. 'Enlightening/cultivating people' with contemporary civilization principles was the aim of the new government. Achieving a civilized society with the help of the built environment was an attempt to transform the everyday life practices of the inhabitants. Accordingly, the new regime was transforming living patterns by introducing modern living environments. The urban plans for the new capital were implying that Turkish Republic was not separate from the wide-reaching ideas of civilized world. Consequently, the designs of foreign architects, such as the urban planners Carl Christoph Lörcher and Hermann Jansen materialized the creative theories of the twentieth century. While constructing the new capital for the increasing population, hundreds of foreign professionals and artisans, largely from Germany and Austria, designed and built the major buildings of the period. Correspondingly, the German construction firm of Philipp Holzmann constructed the initial buildings in the private farm of Mustafa Kemal in 1925 and 1926. Moreover, Forest Farm is the first planned urban open space in such a scale, in the first planned city of Turkey. In 1934, Swiss architect Ernst Egli (1893-1974), appointed the head architect of the Turkish Ministry of Education, prepared the urban design of the farm (Figure 7) (6). The farm buildings were designated to be modern in style. Therefore, Egli designed the Marmara Köşk of Mustafa Kemal, the Turkish Bath, the Brewery, dwellings for the workers, dwelling for Mustafa Kemal's adopted daughter Ülkü and the 10th Year School as well.

Similar to the cases of Agro Pontino and New Deal, architecture served to legitimate the policies of new republic while transforming the social and cultural patterns in Turkey. Both the initial buildings for Forest Farm by the German construction firm Philipp Holzman and the main urban design project prepared by the Swiss architect and urban planner Ernst

6. Egli worked for the Turkish Republic as chief architect at the Ministry of Education and then as the Dean of Faculty of Architecture at the Fine Arts Academy, İstanbul. After returning back to Zurich, he gave lectures on urban planning theory and on history at the Zurich Technical University (ETH). During those years, he wrote his memoir, including the establishment process of the Turkish nation-state, which can be reached from ETH-Bibliothek, Zurich.
Egli represented 'civilization'. Obviously, the everyday life of the civilized world was experienced in this newly constructed environment of the Farm. It formed the visual setting for the production of the ideal citizen of the republic. As a recreational space for leisure activities, this was the space where the signs and symbols of the civilization were exhibited. Consequently, in the rapid construction process, the former rural town of Ankara gained political power against İstanbul and its supporters, in conjunction with the built environment of Forest Farm. 
Figure 7. The first urban design for the Gazi Forest Farm by Ernst Egli. Source: TC Cumhurbaşkanlığı Atatürk Arşivi, Dolap 17, Kutu No: 184-6, Dosya No: 7, Fihrist No: 6-1 ve 6-2.

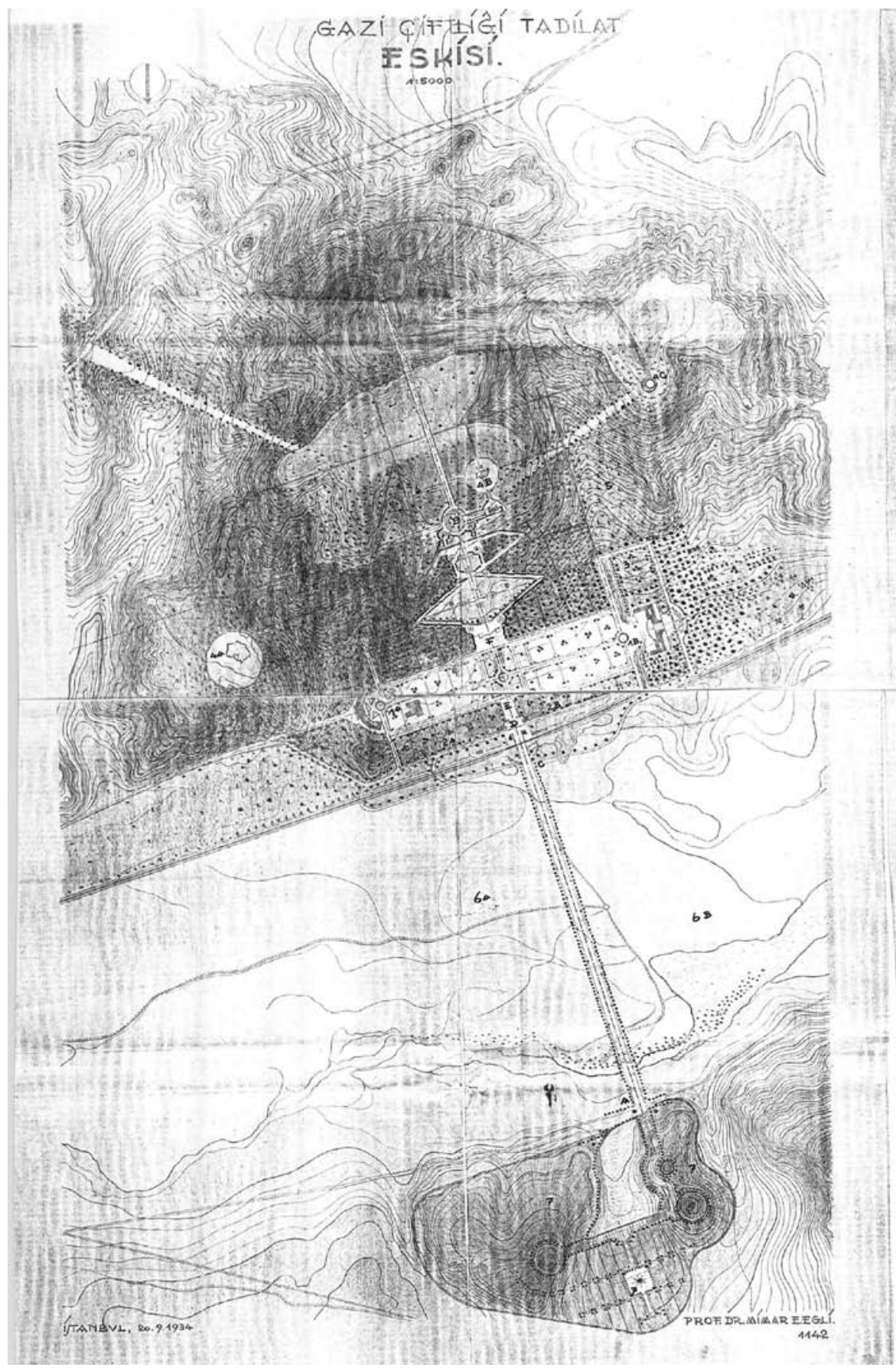

\section{A NETWORK OF REPRESENTATIONS}

Other than the five chronological definitions of culture, the counter of anthropological view links the two definitions of 'a way of life' and 'the production of meaning'. While describing culture as 'an active component in the production and reproduction of social life', this definition covers the dynamic qualities of cultural flows. Culture is "a network of representations - texts, images, talk, codes of behavior and the narrative structures organizing these - which shapes every aspect of social life" (Frow and Morris, 1993, viii). In this regard, documentaries of the period, 
both on Ankara and Forest Farm, are worth discussing as reflections of the new culture and as tools in the production and reproduction of social life.

In 1930s, Mussolini used the act of draining swamplands and the land reclamation as a propaganda subject in the films such as Le Imprese la grande bonifica, Storia di un Avventura Meravigliosa and La bonifica delle Paludi Pontine. In the same years, the Roosevelt administration also used the new technology of motion pictures with sound for spreading its policies and philosophy. The Road is Open Again, Dawn Strikes the Capitol Dome, We Work Again, and The Valley of the Tennessee were among those films that were produced by the Works Progress Administration. For reaching crowds, films were fitting the aim of reflecting the construction of the capital and its ideology in the Turkish Republic, too.

The Turkish nation was proud of the work done in the lands of Forest Farm. Scientific production methods with modern irrigation techniques, cultivation of rare crops, efficiency in stock raising and aforestration in the barren lands of Ankara represented civilization. Visiting diplomats were welcomed in this modern environment, in which the new practices of life, goods of consumption, new ways of clothing and new gender relations were demonstrated. Therefore, before everything else, the documentary, Ghazi Mustafa Kemal in Atatürk Forest Farm (Gazi Mustafa Kemal, Atatürk Orman Çiftliği'nde) was recorded in 1930 to exhibit Forest Farm as the modern environment of the new regime (Cankaya.gov.tr, 2010). In the meeting of Mustafa Kemal with the US ambassador Joseph C. Grew at the Farm, his wife Latife Hanım can be seen accompanying the president together with the farm manager Tahir Coşkan and several other officials. The most important thing is that the farm manager Tahir Coşkan introduces the first five years of the farm in detail, after the short presentation of Mustafa Kemal. The well-known picture of Mustafa Kemal demonstrating modern agriculture techniques on a tractor was taken during this visit of the US ambassador as well. Consequently, this documentary as a primary source also reflects the place of Forest Farm in international relations. The second documentary on the Farm was probably recorded the same day with another name, Mustafa Kemal Atatürk's Address to Americans (Gazi Mustafa Kemal'in Amerikalılara Hitabi). In his speech to Americans, Mustafa Kemal mentions the genesis of the Turkish and American nations' sincerity and ends his words by wishing peace for the world (Cankaya.gov.tr, 2010). Forest Farm was the space where Mustafa Kemal gave his well-known peace messages to foreign countries.

The other documentary on the construction of the new capital and the production of the new citizen is Ankara: The Heart of Turkey (Türkiye'nin Kalbi Ankara, 55:30 minutes). This is much more of a propaganda film since it was ordered from Russian filmmakers for the tenth anniversary of the Turkish Republic (Cankaya.gov.tr, 2010). Dwelling on the oppositions of old and new, traditional and modern, elder and young, ancient and contemporary, and so on, this film underlines the philosophy of the new government, its success, the will of development and the rapid change in living patterns (7). This record ends with the tenth-year speech of Mustafa Kemal, giving messages to his nation and to the world.

\section{CONCLUSIONS}

7. For a broad discussion of the documentary,

Understanding the roots of Forest Farm is crucial for shaping its future. The please see Sargin (2005). 
as an agent of social and cultural transformation in the early Republican period. With all its properties of the cultivation of barren lands, the education of young generations, the transformation of peasants to farmers, the transformation of inhabitants to citizens, and the demonstration of modern urban culture; Forest Farm represented civilization, enlightenment, development, production and the rejection of colonial relationship since the beginning. It is the product of the modern world and the contemporary civilization. Forest Farm is the built environment of the Republic and the model of self-sufficiency for the entire Anatolia. Its existence helped to transform the rural town of Ankara into the Ankara of Mustafa Kemal. Therefore, both Ankara and Forest Farm became the symbol of social awareness, effort and success when the world was witnessing dramatic changes. For these reasons, the present study proves that the genesis of Forest Farm is original and unique compared to its contemporaries.

This unique built environment is a part of the collective memory of the Turkish nation and it has become the subject of conservation. It is a firstdegree cultural and natural site since it had been the stage for historical events during the establishment period of the Turkish Republic. Moreover, among a variety of spaces for production and recreation, the dwellings for Mustafa Kemal Atatürk were built in this specific site, too. As Günay mentions $(2009,151)$, "conservation of natural and cultural beings and their perpetuation through various policies of reproduction of urban space will mean the perpetuation of the human being itself". Consequently, Atatürk Forest Farm is related to the being of the Turkish nation for meeting its past and its culture. For that reason, the consciousness of the public will help more comprehensive and careful conservation of Forest Farm as a being, with all its distinguishing qualities that have made it unique.

\section{BIBLIOGRAPHY}

ATA, B. (2010) John Dewey ve Türkiye' de İlköğretimde Tarih Öğretimi (1923-1930), available at: http:/ / www.egitim.aku.edu.tr/bahriata4. doc (last visited 10.09.2010).

BERKES, N. (2002) Batııllk, Ulusçuluk ve Toplumsal Deorimler, Kaynak Yayınlanı, İstanbul.

BOCOCK, R. (1992) The Cultural Formations of Modern Society, Formations of Modernity, eds. S. Hall, B. Gieben, Polity with Open University Press, Cambridge 229-74.

CANKAYA.GOV.TR (2010) available at: http: / / cankaya.gov.tr/pages / ata_special/video/ (last visited 10.09.2010).

CAPROTTI, F. (2007) Destructive Creation: Fascist Urban Planning, Architecture and New Towns in the Pontine Marshes, Journal of Historical Geography, v: 33 (3) 651-79.

CENGİZKAN, A. (2004) Ankara'nın Ilk Planı 1924-25 Lörcher Planı: Kentsel Mekan Özellikleri, 1932 Jansen Planı'na ve Bugüne Katkıları, Etki ve Kalıntıları, Ankara Enstitüsü Vakfı, Arkadaş Yayıncılık, Ankara.

De GRAND, A. J. (1995) Fascist Italy and Nazi Germany: The Fascist Style of Rule, Routledge, London and New York.

DEWEY, Jane (1939) Biography of John Dewey, The Philosophy of John Dewey, ed. P. A. Schilpp, Tudor Publishing Company, New York; 3-45. 
DURU, K. N. (1947) Atatürk ve Kültürümüz, Babıali Matbaası, İstanbul.

FROW, J., MORRIS, M. eds. (1993) Australian Cultural Studies: A Reader, St Leonards, Allen and Unwin.

GHIRARDO, D. (1989) Building New Communities: New Deal America and Fascist Italy, Princeton University Press, Princeton.

GÜNAY, B. (2009) Conservation of Urban Space as an Ontological Problem, METU Journal of the Faculty of Architecture, v: 26 (1) 123-56.

GÜVENÇ, B. (2003) Türk Kimliği: Kültür Tarihinin Kaynaklarl, Remzi Kitabevi, İstanbul.

KAÇAR, A. D. (2010) Cultivating the Nation: Atatürk's Experimental Farm as an Agent of Social and Cultural Transformation, unpublished Ph.D. Dissertation, Middle East Technical University, Ankara.

KARAÖMERLIOĞLU, A. (2006) Orada Bir Köy Var Uzakta: Erken Cumhuriyet Döneminde Köycü Söylem, İletişim Yayınları, İstanbul.

KIRK, T. ed. (2005) The Architecture of Modern Italy: Volume II, Princeton Architectural Press, NY.

SARGIN, G. A. (2005) Ötekinin Gözüyle Ankara'yı Kurmak: Sovyet Propaganda Filmlerinde Devrimci Bellek Kaybı ve Anımsama, 'Cumhuriyet'in 'Ankara'sl, ed. T. Şenyapılı, ODTÜ Yayıncılık, Ankara; 366-401.

SCHECH, S., HAGGIS, J. (2000) Culture and Development: A Critical Introduction, Wiley-Blackwell Publishers, Oxford, Malden, Mass.

SELIGMAN, L. G., CORNWELL, E. E. Jr. eds. (1965) New Deal Mosaic: Roosevelt Confers With His National Emergency Council 1933-1936, University of Oregon Books, Eugene, Oregon.

WIKIPEDIA.ORG (2010) available at: http: / / en.wikipedia.org/wiki / Pontine_Marshes (last visited 15.09.2010).

Alınd1: 28.12.2010, Son Metin: 10.05.2011

Anahtar Sözcükler: kültür; tarım; üretim; eğitim; gelişim; uygarlık; anlam; temsiliyet, mekansal pratik; Atatürk Orman Çiftliği.

\section{SOSYAL VE KÜLTÜREL ÖRÜNTÜLERINN DÖNÜŞÜMÜ ICÇIIN BENZERSİZ BİR MEKANSAL PRATIKK: ATATÜRK ORMAN ÇİFTLİĞİ ANKARA}

Atatürk Orman Çiftliği, modern tarım ve endüstriyel üretim tekniklerinin boş zaman aktiviteleri ile birleştirilmesiyle bir kent çiftliği olarak geliştirilen ve Türkiye Cumhuriyeti'nin temel felsefesi olan yeni bir toplum yaratma ilkesini temsil eden benzersiz bir mekansal pratiktir. Bu çalışmada Orman Çiftliği'nin varlığı, Türk ulusunun kültürel dönüşümü için bilinçli bir katkı olarak değerlendirilmektedir. Bu nedenle, varoluşu tarih içindeki temel kültür tanımları ile bağlantılı olarak tartışılmaktadır: 1) ürünlerin ve toprağın verimini artırmak fikri ile 'doğanın işlenmesi'; 2 ) bireylerin eğitimi bağlamında 'zihinlerin terbiye edilmesi'; 3) 'sosyal gelişim süreci'; 4) 'anlamlar, değerler, yaşam biçimleri'; 5) ‘anlamları üreten pratikler'; ve son olarak 6) 'temsil ağı' olarak 'yaşam tarzı' ve 'anlamın üretimi' tanımlarını bağlayan antropolojik bakış açılarının birbirine geçişi. Bu bağlamda,

a) Orman Çiftliği, kurulduğu tarihlerdeki ileri toplumların benzer 
yapılanmadaki örnekleri olan İtalya'daki Agro Pontino ve Amerika'daki New Deal ile karşılaştırılmaktadır; b) Amerikalı ilerici eğitimci John Dewey' nin 'yaparak öğrenme' felsefesinin etkileri çerçevesinde Amerika' da bilimsel üretim, verimlilik ve toplumsal yaşamın onarımını hedefleyen 4-K'nın kurgusu ile Orman Çiftliği' nin benzerlikleri tartışılmaktadır; c) 1870'lerden itibaren Rusya, Bulgaristan ve Doğu Avrupa'da ekonomik kalkınmanın ön şartı olarak görülen 'köylünün eğitilmesi' hareketinin henüz sanayileşmemiş Türk toplumunun 'kendine yetebilme' ve 'bağımsızlık' mücadelesi ile ilişkisi kurulmakta, Orman Çiftliği'nin 'köylü' nün 'çiftçi'ye dönüştürülmesindeki katkıları sorgulanmaktadır; d) Yeni rejimin mekanı ve Ankara'nın uygar yüzü olarak Orman Çiftliği kent sakinleri için bir açık hava okulu olarak değerlendirilmektedir; e) Osmanlı' nın başkenti İstanbul'dan Cumhuriyet'in başkenti Ankara'ya geçişte yirminci yüzyılın yaratıcı felsefesini yansıtacak biçimde tasarlanan ilk kentsel açık alanlar arasında yer alan Çiftlik'in İsviçre'li tasarımcısı Ernst Egli'nin katkıları ile uygarlığın ve Cumhuriyet' in temsili haline gelmiş olduğu irdelenmektedir; f) 1930 tarihli Gazi Mustafa Kemal, Atatürk Orman Çiftliği'nde ve Gazi Mustafa Kemal'in Amerikalılara Hitabı adlı filmlerin, misafir diplomatların ağırlandığı, yeni yaşam pratiklerinin, tüketim maddelerinin, giyim biçimlerinin ve cinsiyet ilişkilerinin sergilendiği mekan olan Orman Çiftliği'nde çekilmesinin ürettiği anlamlar tartışılmaktadır. Bu calışma ile, Atatürk Orman Çiftliği ile benzerlik gösteren pek az deneyimin olduğu, ancak kültürün dönüştürülmesinde bir araç olması durumunun benzersiz olduğu kanıtlanmıştır.

A. DUYGU KAÇAR, B.Arch., M.Arch., Ph.D.

Studied architecture at Gazi University (B.Arch., 1999). Received her M. Arch (2002) and Ph.D. (2010) degrees from the Department of Architecture at METU. Worked as a research assistant in the same department between 2004 and 2011. Visiting scholar at George Washington University (2008) and at TU, Dortmund (2010) for her doctoral research. duygukacar@hotmail. com, $\underline{\text { duygukacar@gmail.com }}$ 